\title{
KAPASITAS PETANI PADA USAHATANI JAGUNG (Zea mays) DI KECAMATAN SUKADANA KABUPATEN CIAMIS
}

\author{
Oleh \\ Dewi Amelia $^{1)}$, Dayat ${ }^{2)}$ \& Nawangwulan Widyastuti ${ }^{3)}$ \\ Jurusan pertanian, Politeknik Pembangunan Pertanian Bogor \\ Email : ${ }^{1}$ dewiamelia098@gmail.com, ${ }^{2}$ drdayatpolbangtan@gmail.com \& \\ 3nawangbambang@gmail.com
}

\begin{abstract}
Abstrak
Kapasitas petani adalah faktor terpenting dalam mengelola sumberdaya alam dan sangatlah diperlukan sebagai faktor penentu keberhasilan usahatani yang dijalankan. Oleh karena itu, perlu adanya kualitas petani/kapasitas petani yang tinggi dengan cara memberikan informasi mengenai usahatani pada saat penyuluhan sehingga tujuan utama dalam mengelola sumberdaya alam dilakukan secara tepat dan dapat menghasilkan. Tujuan dari penelitian ini adalah untuk menentukan tingkat kapasitas petani, menganalisis faktor-faktor yang mempengaruhi dan merumuskan strategi peningkatan kapasitas petani. Penelitian ini dilakukan di Kecamatan Sukadana Kabupaten Ciamis Provinsi Jawa Barat. Data yang digunakan dalam kegiatan penelitian ini berupa data primer dan data sekunder dilakukan dengan wawancara terstruktur, angket (kuesioner) dan observasi. Kuesioner dibagikan kepada petani yang berusahatani jagung, dengan jumlah responden sebanyak 30 orang. Hasil penelitian menunjukan bahwa kapasitas petani dalam usahatani jagung secara umum rata-rata termasuk kedalam kategori sedang yaitu dalam melakukan perencanan, pelaksanaan, membangun jejaring dan mengevalusi usahatani. Faktor-faktor yang mempengaruhi kapasitas petani dalam penelitian ini yaitu faktor pendukung dengan nilai signifikan 0,006 dan penyelenggaraan penyuluhan dengan nilai signifikan 0,016 . Strategi yang digunakan untuk meningkatkan kapasitas petani dalam melakukan kegiatan usahatani jagung ini yaitu dengan melakukan penyuluhan kepada para petani maupun kelompok tani secara rutin sehingga kapasitas petani meningkat.
\end{abstract}

\section{Kata Kunci : Kapasitas petani, Usahatani \& Penyuluhan Pertanian}

\section{PENDAHULUAN}

Sistem pembangunan yang berkelanjutan dan berwawasan lingkungan perlu ditumbuhkembangkan dalam pembangunan pertanian secara menyeluruh dan terpadu (Undang - Undang No 12 Tahun 1992). Pertanian ini mempunyai peranan penting dalam pencapaian tujuan pembangunan nasional yaitu terciptanya masyarakat adil dan makmur berdasarkan Pancasila dan Undang Undang Dasar 1945.

Penyuluhan pertanian merupakan suatu sistem pembelajaran yang diberikan dari penyuluh kepada para petani dengan tujuan untuk meningkatkan pengetahuan sikap dan keterampilan petani dalam usaha taninya sehingga tercapai kesejahteraannya.
Keberhasilan atau tidaknya kegiatan penyuluhan pertanian yang dilakukan dapat memberikan dampak terhadap pembangunan pertanian masa depan, karena penyuluhan pertanian merupakan salah satu kegiatan yang strategis dalam upaya pencapaian tujuan pembangunan pertanian dengan melibatkan aspirasi serta peran aktif petani dan pelaku usaha tani melalui pendekatan partisipatif.

Kapasitas merupakan kemampuan individu, organisasi atau sistem untuk menjalankan fungsi sebagaimana mestinya secara efektif, efisien dan terus-menerus (Milen, 2004). Setiap individu memiliki kapasitas yang melekat pada dirinya yaitu karakteristik, yang merupakan salah satu faktor yang mendasari tingkah laku seseorang. 
Kapasitas yang dimaksudkan dalam penelitian disini yaitu kapasitas petani dalam menjalankan usaha taninya mulai dari persiapan hingga tahapan evaluasi dalam berusaha tani. Tujuan adanya pengukuran kapasitas petani dalam melakukan usaha tani ini yaitu untuk meningkatkan hasil produktivitas dari tahun ke 1 . tahun sehingga kurva pertumbuhan usaha tani meningkat.

Tanaman jagung (Zea mays) merupakan 2. salah satu jenis tanaman di Indonesia yang sangat potensial yang artinya mempunyai potensi yang baik yaitu sebagian besar untuk 3 . kebutuhan pakan dan dimanfaatkan untuk kebutuhan industri. Selain itu tanaman jagung banyak dimanfaatkan untuk kebutuhan pangan karena dapat menyehatkan bagi tubuh manusia, sehingga perlu dibudidayakan lebih banyak lagi untuk kesejahteraan dan memenuhi kebutuhan 1 . tersebut. Produksi tanaman jagung pada tahun 2018 produksi jagung di Kabupaten Ciamis dari tahun ke tahun mengalami penurunan yaitu 2 . pada tahun 20187760,12 dan pada tahun 2019 sekitar 6673,9 sehingga menurun -13,99\% (Programa BPP Kecamatan Sukadana).

Kabupaten Ciamis merupakan salah satu daerah di Jawa Barat yang banyak menghasilkan produk pangan dengan sumberdaya alam yang sangat mendukung yakni dengan kesuburan tanahnya hal ini menjadi suatu peluang bagi para petani dalam berusahatani. Kualitas SDM sangat mempengaruhi tingkat produktivitas yang dihasilkan pada usahatani. Berdasarkan hasil observasi/survei lapangan yang dilakukan di wilayah Kecamatan Sukadana melalui wawancara terhadap para petani, pihak terkait bidang pertanian serta penyuluh lapangan, petani masih belum maksimal dalam melakukan kegiatan usahatani jagung. Selain itu didukung oleh data dari Desa, BPP Sukadana baik itu profil Desa dan programa BPP Sukadana tahun 2019 bahwa tingkat PSK petani pada usahatani jagung baru 50\%. Maka diduga tingkat kapasitas petani masih kurang/sedang, oleh karena itu penulis ingin mencari tahu faktor-faktor yang mempengaruhi tingkat kapasitas petani sehingga dapat menentukan strategi untuk meningkatkan kapasitas petani pada usahatani jagung.

Masalah yang dapat dirumuskan dalam pengkajian mengenai kapasitas petani pada usahatani jagung (Zea mays) ini yaitu:

Seberapa besar tingkat kapasitas petani pada usahatani jagung (Zea mays) di Kecamatan Sukadana?

Faktor - faktor apa saja yang mempengaruhi kapasitas petani pada usahatani jagung (Zea mays) di Kecamatan Sukadana?

. Bagaimana strategi untuk meningkatkan kapasitas petani pada usahatani jagung (Zea mays) di Kecamatan Sukadana?

Tujuan dilakukannya pengkajian mengenai kapasitas petani pada usahatani jagung (Zea mays) yaitu :

. Mendeskripsikan tingkat kapasitas petani pada usahatani jagung (Zea mays) di Kecamatan Sukadana

Menganalisis faktor - faktor yang mempengaruhi kapasitas petani pada usahatani jagung (Zea mays) di Kecamatan Sukadana

3. Merumuskan strategi peningkatan kapasitas petani pada usahatani jagung (Zea mays) di Kecamatan Sukadana

\section{LANDASAN TEORI \\ Penyuluhan Pertanian}

Penyuluhan pertanian adalah salah satu proses pembelajaran yang dilakukan oleh pelaku utama serta pelaku usaha agar mereka mau dan mampu menolong dan mengorganisasikan dirinya dalam mengakses berbagai macam informasi teknologi, pasar, permodalan serta sumberdaya lainnya yang mendukung usaha pertanian tersebut, sehingga dapat meningkatkan produktivitas, efisiensi usaha, pendapatan, kesejahteraan serta meningkatkan kesadaran dalam pelestarian lingkungan hidup (Undang - Undang Nomor 16 tahun 2006).

Tujuan penyuluhan pertanian sebagai alat untuk membantu dan memfasilitasi para petani beserta keluarganya untuk mencapai tingkat usahatani yang lebih produktif, taraf 
kehidupan keluarga dan masyarakat yang lebih memuaskan melalui kegiatan-kegiatan yang terencana untuk mengembangkan kemampuan petani itu sendiri sehingga terjadinya peningkatan ekonomi (Padmanagara, 2012).

Materi penyuluhan merupakan bahan kegiatan penyuluhan yang akan disampaikan oleh para penyuluh kepada pelaku utama tau pelaku usaha dalam berbagai bentuk yang meliputi teknologi, informasi, manajemen, ekonomi, rekayasa sosial, hukum serta kelestarian lingkungan (Undang - Undang Nomor 16 tahun 2006).

\section{Petani}

Petani adalah orang yang memiliki dan menggarap lahan miliknya sendiri dengan memanfaatkan segala sumber daya hayati yang ada seperti bercocok tanam, beternak untuk keberlangsungan hidup rumah tangga petani itu sendiri (Slamet, 2000). Dalam kegiatan usahatani, supaya dapat menghasilkan keuntungan maka perlu adanya penerapan teknologi inovasi secara berkelanjutan. Hal ini merupakan salah satu upaya pemerintah dalam proses pencapaian pembangunan pertanian yaitu meningkatkan produktivitas hasil pertanian. Faktor - faktor yang mempengaruhi petani dalam penerapan suatu inovasi dipengaruhi oleh karakteristik petaninya itu sendiri, faktor pendukung serta penyelenggaraan penyuluhan.

\section{Kapasitas Petani}

Menurut Milen (2004), kapasitas merupakan kemampuan individu, organisasi atau sistem untuk menjalankan fungsi sebagaimana mestinya secara efektif, efisien dan terus-menerus sehingga dapat mencapai tujuan sesuai dengan apa yang diharapkan. Setiap individu secara alamiah memiliki kapasitas yang melekat pada dirinya sendiri, dengan kata lain dapat disebut karakteristik. Kapasitas petani merupakan suatu kemampuan, karakter serta tingkah laku yang dimiliki oleh petani dalam menjalankan usahataninya. Kapasitas petani akan mempengaruhi usahatani yang dihasilkan. Oleh karena itu perlu adanya dukungan supaya kapasitas petani dapat meningkat.
Usahatani

Usahatani adalah kegiatan usaha manusia untuk mengusahakan sumber daya alam dengan maksud memperoleh hasil tanaman atau hewan tanpa menurunkan tingkat sumber daya alam serta kemampuan lahan yang bersangkutan memperoleh hasil selanjutnya (Salikin, 2003). Kegiatan usahatani akan menguntungkan apabila kegiatan pengelolaannya dilakukan dengan baik sehingga secara terus menerus dapat dimanfaatkan dan menghasilkan. Kegiatan usahatani ini biasanya berkaitan dengan pengambilan keputusan tentang apa, kapan, dimna dan berapa besar skala usaha yang dijalankan. Kegiatan usahatani dipengaruhi oleh beberapa faktor yang dapat mempengaruhi diantaranya faktor sosial ekonomi meliputi umur, tingkat pendidikan, pengalaman usahatani, jumlah tanggungan keluarga serta kepemilikan lahan (Tambunan, 2003).

\section{Karakteristik Petani}

Menurut Abdul Halim dkk, 1992 menerangkan bahwa karakteristik individu merupakan ciri-ciri yang dimiliki seseorang dengan semua aspek dan lingkungannya dan terbentuk oleh faktor biologis dan sosiopsikologis. Karakteristik individu merupakan salah satu faktor yang penting untuk diketahui dalam rangka mengetahui suatu perilaku dalam masyarakat. Serta didalam karakteristik individu ini mempunyai ciri-ciri atau sifat-sifat individual yang berhubungan dengan semua aspek kehidupan dan lingkungan seseorang. Dalam karakteristik individu ini dapat diidentifikasi maupun dilihat dari beberapa hal diantaranya umur, pendidikan, luas lahan dan pengalaman usaha tani. Karakteristik petani sangat menentukan hasil pemahaman terhadap informasi.

\section{Faktor Pendukung}

Faktor pendukung dalam kegiatan usahatani merupakan faktor yang mendukung, mengajak serta ikut serta dalam suatu kegiatan supaya tujuan dapat tercapai. Faktor pendukung dalam kegiatan usahatani ini diantaranya kelompok tani, ketersediaan teknologi 
informasi, ketersediaan sarana prasarana dan inovasi.

\section{Penyelenggaraan Penyuluhan}

Pertanian

Peraturan Menteri Kementerian

Nomor.03/Permentan/SM.200/1/2018

menerangkan tentang pedoman penyelenggaraan penyuluhan pertanian dengan tujuan untuk mengelola sistem kelembagaan penyuluhan pertanian baik itu pemerintah, swasta dan swadaya serta instansi terkait mulai dari pusat, provinsi, kabupaten, kecamatan hingga kelurahan dan pemangku kepentingan lainnya.

\section{Budidaya Jagung (Zea mays)}

Jagung (Zea mays) merupakan salah satu komoditi tanaman pangan yang utama yang berpotensi dikembangkan di Indonesia. Jagung memiliki banyak manfaat baik untuk dikonsumsi maupun sebagai bahan pakan ternak serta kebutuhan industri. Persyaratan tumbuh tanaman jagung (Zea mays) ini ditanam di dataran rendah antara 50 - $450 \mathrm{mdpl}, \mathrm{pH}$ optimal untuk tanaman jagung itu sendiri yaitu $\mathrm{pH}$ 5,6 - 7,5 dan suhu optimum yang cocok untuk tanaman jagung (Zea mays) $23^{\circ} \mathrm{C}-30^{\circ} \mathrm{C}$, dengan kelembaban serta penyinaran yang cukup untuk menghasilkan pertumbuhan yang optimal, sehingga dengan memperhatikan karakteristik tanaman akan meningkatkan produktivitas jagung. Keasaman tanah merupakan hal yang sangat penting untuk pertumbuhan tanaman jagung, perlu diperhatikan tingkat keasaman jagung maksimal antara 5,5 sampai 7. Penanaman tanaman jagung ditanam secara serempak, agar diperoleh tanaman dengan pertumbuhan yang seragam (BPTP BALITBANG KEPRI, 2018).

\section{Budidaya Tanaman}

1. Benih, benih yang digunakan adalah benih yang baik, benih yang mempunyai potensi yang tinggi, tahan terhadap hama penyakit, daya tumbuh lebih dari $90 \%$.

2. Persiapan Lahan, persiapan lahan diperlukan untuk mendapatkan tanah yang subur dan gembur, Selain itu juga untuk menghilangkan gulma dan sisa pertanaman sebelumnya agar tidak mengganggu pertumbuhan jagung sehingga tanaman tumbuh dengan baik.

3. Penanaman, dalam penanaman jagung (Zea mays) ini sebaiknya dibuat lobang tanam

4. Pemupukan, pemupukan yang baik untuk budidaya jagung (Zea mays) adalah tanah yang kaya bahan organik, mempunyai salinitas rendah dan tidak mengandung senyawa toksik.

5. Pemeliharaan, meliputi penyulaman penyiangan, pembumbunan dan pengairan

6. Pengendalian Organisme Pengganggu Tumbuhan (OPT), pengendalian dilakukan untuk mengendalikan hama pada tanaman.

7. Panen dan Pascapanen Jagung (Zea mays) pemanenan dapat dilakukan setelah tanaman jagung (Zea mays) berumur 86 - 96 hari setelah tanam atau tergantung varietas yang ditanam. Pemanenan dilakukan dengan cara memutar tongkol dan klobotnya dengan mematahkan tongkol jagung. Sedangkan dalam kegiatan pascapanen jagung diantaranya pengumpulan hasil, pengupasan, pengeringan, pemipilan, penyortiran, grading, penyimpanan hingga pemasaran.

\section{Kerangka Berpikir}

Gambar 1. Kerangka Berpikir Kapasitas Petani Pada Usahatani Jagung (Zea mays )

Di Kecamatan Sukadana Kabupaten Ciamis

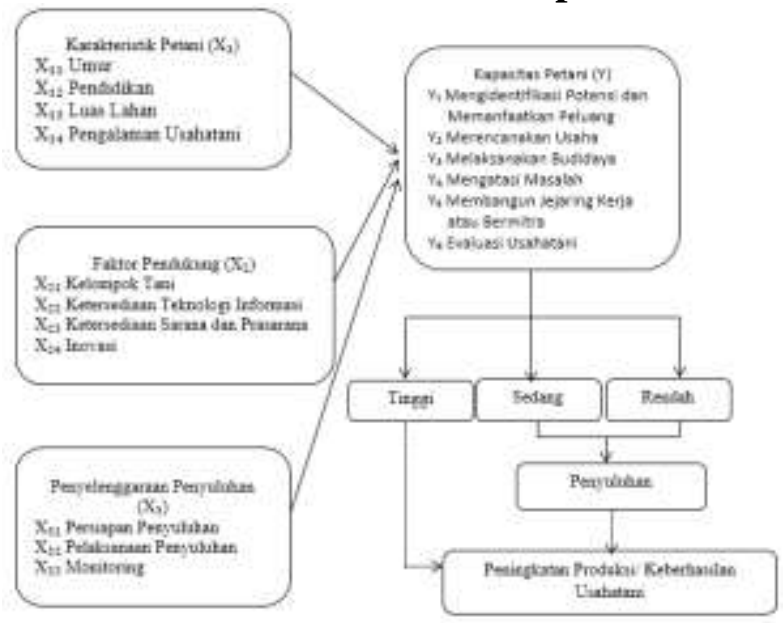




\section{METODE PENELITIAN}

\section{Waktu dan Tempat}

Pelaksanaan kegiatan pengkajian telah dilaksanakan selama empat bulan, terhitung dari bulan Maret sampai dengan bulan Juni 2020. Lokasi pelaksanaan kajian Tugas Akhir ini telah dilaksanakan di Desa Margaharja dan Margajaya Kecamatan Sukadana Kabupaten Ciamis Provinsi Jawa Barat.

\section{Populasi dan Sampel}

Pengkajian dilakukan di dua lokasi Desa yang berbeda pada populasi petani jagung yaitu Desa Margaharja dan Desa Margajaya. Kedua Desa tersebut merupakan sentra jagung di Kecamatan Sukadana. Populasi diambil sebanyak empat kelompok tani yaitu kelompok tani mekar mukti, mekarsari, bukit mekar dan lengkong sari dengan total populasi secara keseluruhan sebanyak 156 orang. Dikarenakan keterbatasan tenaga, biaya dan waktu, kegiatan pengkajian ini dilakukan dengan mengambil sampel dari populasi yang ada yaitu menggunakan teknik probability sampling dengan proportionate stratified random sampling. Sampel yang dijadikan sebagai responden ditetapkan melalui perhitungan dengan menggunakan rumus slovin, sehingga diperoleh hasil sebanyak 30 orang responden.

\section{Instrumen}

Instrumen yang digunakan dalam pengkajian ini berupa kuesioner yaitu kuesioner tertutup dan kuesioner tebuka. Instrumen disusun untuk mendeskripsikan serta mengetahui faktor-faktor yang mempengaruhi kapasitas petani pada usahatani jagung yang telah dirumuskan sebelumnya meliputi $\left(\mathrm{X}_{1}\right)$ Karakteristik Petani, $\left(\mathrm{X}_{2}\right)$ Faktor Pendukung, $\left(\mathrm{X}_{3}\right)$ Penyelenggaraan Penyuluhan, terhadap $\left(\mathrm{Y}_{1}\right)$ Kemampuan Identifikasi Potensi, $\left(\mathrm{Y}_{2}\right)$ Kemampuan Merencanakan Usahatani, $\left(\mathrm{Y}_{3}\right)$ Kemampuasn Melaksanakan Budidaya, $\left(\mathrm{Y}_{4}\right)$ Kemampuan Mengatasi Masalah, $\left(\mathrm{Y}_{5}\right)$ Kemampuan Membangun Jejaring dan $\left(\mathrm{Y}_{6}\right)$ Kemampuan Mengevaluasi Usahatani.

\section{Pengumpulan Data dan Analisis Data}

Data yang digunakan dalam pengkajian ini yaitu data primer dan data sekunder. Teknik pengumpulan data dalam pelaksanaan pengkajian ini dilakukan dengan cara observasi, wawancara dan pengisian angket atau kuesioner. Teknik analisis data yang digunakan dalam pengkajian ini yaiitu analisis deskriptif untuk mendeskripsikan tingkat kapasitas petani serta merumuskan strategi untuk meningkatkan kapasitas petani dan analisis regresi linier berganda untuk mengetahui faktor-faktor yang mempengaruhi kapasitas petani dalam usahatani jagung.

\section{HASIL DAN PEMBAHASAN Keragaan Wilayah}

Kecamatan Sukadana terletak di Bagian Utara Kabupaten Ciamis yang berjarak $18 \mathrm{~km}$ dari Ibu Kota Kabupaten, meliputi 6 (Enam) Desa dan 43 (Empat Puluh Tiga) Dusun. Geografis wilayah Kecamatan Sukadana pada koordinat $108^{\circ} 24,50$ ", sampai dengan $108^{\circ} 29^{\prime} 45^{\text {' }}$ Bujur Timur dan $7^{\circ} 13^{\prime} 10^{\prime}$ " sampai dengan $7^{\circ} 19^{\prime} 15^{\prime}$ ' Lintang Selatan. Luas wilayah Kecamatan Sukadana 5.828 hektar terdiri dari lahan sawah 841 ha $(14,43 \%)$ dan lahan kering $4987(85,57 \%)$ dengan jumlah penduduk sebanyak 24.042 orang. Keadaan topografi terdiri atas pedataran dan pegunungan dengan ketinggian tempat $\leq$ 350 mdpl. Wilayah Kecamatan Sukadana memiliki jenis tanah Latosol, Podsolik merah kuning dan memiliki type iklim, yaitu iklim basah (agak Basah). Dengan rata-rata curah hujan $35,80 \mathrm{~mm}$.

Desa Margajaya terletak di wilayah bagian utara kecamatan Sukadana dengan jarak dari pemerintah Kecamatan sejauh $3 \mathrm{~km}$. Desa Margajaya berada di titik koordinat 108.424064 LS/LU 7.23573 BT/BB dengan 672,23 Ha. Luas Desa Margajaya yaitu 672,23 Ha. Bedasarkan ekosistem luasan lahan desa Margajaya terdiri atas: lahan sawah seluas $108 \mathrm{Ha}$, lahan ladang seluas 48 $\mathrm{Ha}$, lahan perkebunan seluas $11 \mathrm{Ha}$, hutan seluas $407 \mathrm{Ha}$ dan lahan lainnya $99 \mathrm{Ha}$. Karakteristik lahan di desa Margajaya memiliki tingkat kemasaman tanah yang cukup bervariasi dari masam (4) sampai dengan netral $(6,5)$. Desa Margajaya terletak di dataran rendah sehingga dominan lebih 
cocok untuk ditanaman berbagai tanaman pangan maupun palawija. Sumberdaya manusia yang sangat potensial dalan program kegiatan pembangunan pertanian yaitu umur penduduk

Desa Margaharja merupakan satu kesatuan masyarakat hukum yang berada di wilayah Kecamatan Sukadana Kabupaten Ciamis yang sekaligus merupakan batas wilayah dengan Kecamatan Rajadesa dan Kecamatan Rancah yang berada pada titik kordinat $30,8^{\circ} \mathrm{LS}$ dan $108.27^{\circ} \mathrm{BT}$ dengan ketinggian dari permukaan laut 230 DPL. Desa Margaharja dengan luas $1.050 \mathrm{Ha}$ terbagi atas 8 (delapan) RW dan 35 (tiga puluh lima) RT. Luas Desa Margaharja yaitu $1.050 \mathrm{Ha}$. Bedasarkan ekosistem luasan lahan desa Margajaya terdiri atas: lahan sawah seluas $345 \mathrm{Ha}$, lahan ladang seluas $500 \mathrm{Ha}$, lahan perkebunan seluas $147 \mathrm{Ha}$, pekarangan seluas $30 \mathrm{Ha}$ dan lahan lainnya $28 \mathrm{Ha}$. Karakteristik lahan di desa Margaharja memiliki tingkat kemasaman tanah yang cukup bervariasi dari masam (4) sampai dengan netral (6,5). Desa Margaharja terletak di dataran rendah sehingga dominan lebih cocok untuk ditanaman berbagai tanaman pangan maupun palawija. Sumberdaya manusia yang sangat potensial dalan program kegiatan pembangunan pertanian yaitu umur penduduk.

\section{Analisis Deskriptif}

\section{Karakteristik Petani}

Karakteristik petani meliputi umur, pendidikan, pengalaman berusahatani dan luas lahan menunjukan persentase yang berbeda. Berdasarkan hasil analisis yang diperoleh menunjukan bahwa tingkat rata-rata karakteristik responden berdasarkan umur berada dalam kategori produktif dengan persentase sebesar 56,7\%, karakteristik responden berdasarkan pendidikan berada dalam tingkat Sekolah Dasar (SD) dengan jumlah persentase sebesar $66,7 \%$, karakteristik responden berdasarkan pengalaman berusahatani berada dalam kategori sedang jumlah persentase sebesar $43,3 \%$ dan karakteristik responden berdasarkan luasan lahan sama rata yaitu rata-rata petani disana memiliki luasan lahan 0-0,5 $\mathrm{Ha}$.

\section{Faktor Pendukung}

Faktor pendukung meliputi kelompok tani, ketersediaan teknologi informasi, ketersediaan sarana prasarana dan inovasi. Berdasarkan hasil analisis yang diperoleh menunjukan bahwa faktor pendukung masing masing indikator memiliki jumlah persentase yang berbeda. Kelompok tanitermasuk kedalam kategori rendah dengan jumlah persentase sebesar 70,0\%, ketersediaan teknologi informasi tergolong kedalam kategori sedang dengan jumlah persentase sebesar $60,0 \%$, ketersediaan sarana prasarana tergolong kedalam kategori rendah dengan jumlah persentase sebesar 46,7 dan inovasi termasuk kategori rendah dengan jumlah persentase sebesar 73,3\%.

\section{Penyelenggaraan Penyuluhan}

Penyelenggaraan penyuluhan meliputi persiapan penyuluhan, pelaksanaan penyuluhan dan evaluasi. Berdasarkan hasil analisis yang diperoleh menunjukan bahwa indikator penyuluhan memiliki tingkatan persentase yang berbeda. Persiapan penyuluhan tergolong dalam kategori rendah dengan jumlah persentase $73,3 \%$, pelaksanaan penyuluhan termasuk kedalam kategori sedang dengan jumlah persentase sebesar $50,0 \%$ dan evaluasi tergolong kedalam kategori sedang dengan jumlah persentase sebesar $66,7 \%$.

Bedasarkan hasil analisis yang telah dilakukan oleh Herawati dkk, 2016 bahwa tingkat kapasitas petani dalam mengelola ushatani tergolong sedang pada kemampuan teknik budidaya, mengatasi permasalahan, melakukan evaluasi dan adaptasi serta kapasitas petani kategori rendah pada kemampuan perencanaan dan kemampuan bermitra. Berikut hasil analisis deskriptif kapasitas petani di Kecamatan Sukadana

\section{Kapasitas Petani}

Kapasitas

petani dalam mengidentifikasi potensi usaha, merencanakan, melaksanakan, mengatasi masalah, 
membangun jejaring kerja serta evaluasi usahatani memberikan nilai atau persentase yang sangat variatif. Hal ini menunjukan bahwa kapasitas petani tiap individu berbeda-beda sehingga perlu adanya satu cara maupun langkah yang dilakukan supaya perbedaan kapasitas dapat menjadikan sebagai kekuatan dalam melakukan kegiatan usahatani.

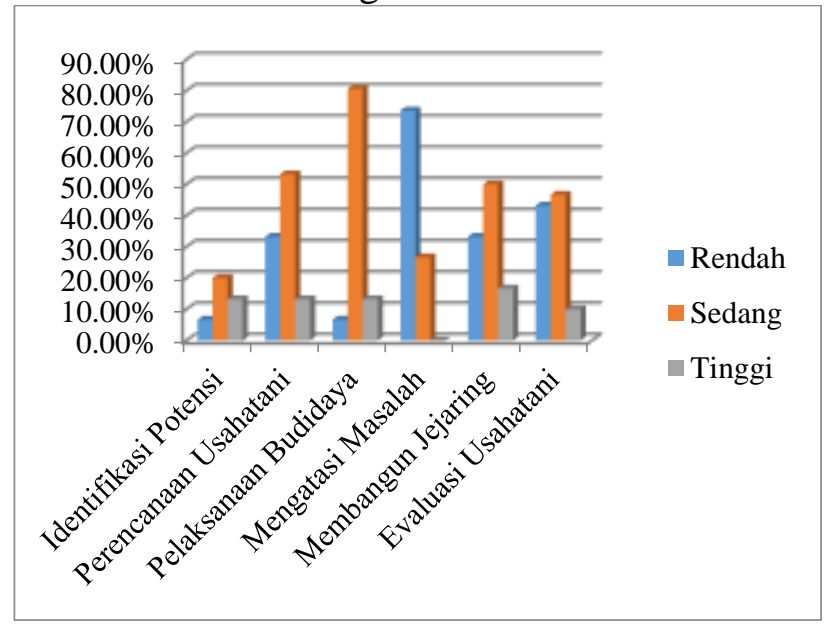

Berdasarkan hasil analisis menunjukan bahwa kapasitas petani bagian identifikasi petani yang termasuk kategori tinggi sebanyak 4 orang dengan jumlah persentase sebesar $13,3 \%$, untuk kategori sedang sebanyak 6 orang dengan jumlah persentase sebanyak $20,0 \%$ dan kategori rendah sebanyak 20 orang dengan persentase sebesar $66,7 \%$. Hal ini menunjukan bahwa tingkatan petani dalam mengidentifikasi kegiatan usahatani di Desa Margaharja dan Desa Margajaya masih dikatakan rendah. Kapasitas petani bagian perencanaan usahatani bahwa kategori tinggi sebanyak 4 orang dengan jumlah persentase sebesar 13,3\%, untuk kategori sedang sebanyak 16 orang dengan jumlah persentase sebanyak $53,3 \%$ dan kategori rendah sebanyak 10 orang dengan jumlah persentase sebesar 33,3\%. Hal ini menunjukan bahwa tingkatan petani atau kapsitas petani di dua Desa tersebut dalam merencanakan usahatani sudah cukup mampu akan tetapi masih kurang maksimal sehingga perlu adanya dukungan serta dorongan dari pihak luar supaya hasil dari kegiatan usahatani yang dilakukan lebih optimal. Kapasitas petani dalam bagian pelaksanaan budidaya bahwa kategori tinggi berjumlah 4 orang dengan persentase sebanyak 13,3\%, untuk kategori sedang sebanyak 24 orang dengan jumlah persentase sebesar $80,0 \%$ dan untuk kategori rendah berjumlag 2 orang dengan jumlah persentase sebesar $6,7 \%$. Hal ini menunjukan bahwa tingkat kapasitas petani di kedua Desa tersebut sebagian besar sudah mengetahui cara pelaksanaan budidaya yang tepat akan tetapi ada beberapa hal yang masih belum banyak dilakukan seperti mengganti varietas tidak menggunakan pupuk organik dan pestisida nabati serta belum memanfaatkan musuh alami.

Berdasarkan hasil analisis menjelaskan bahwa kategori dalam mengatasi masalah untuk kategori sedang berjumlah 8 orang dengan persentase $26,7 \%$ dan untuk kategori rendah sebanyak 22 orang dengan jumlah persentase sebesar 73,3\%. Hal ini menunjukan bahwa kapasitas petani dalam mengatasi masalah yang ada dalam kegiatan usahataninya masih rendah salah satunya mengatasi masalah dalam pengelolaan air yang dimana tidak adanya pengairan khusus dan lahan masih lahan tadah hujan, selain itu pengendalian hama penyakit yang masih kurang maksimal sehingga menurunkan produktivitas hasil. Kapasitas petani dalam membangun jejaring kerja/bermitra bahwa kategori tinggi berjumlah 5 orang dengan persentase sebesar 16,7\%, kategori sedang sebanyak 15 orang dengan jumlah persentase sebesar $50,0 \%$ dan untuk kategori rendah sebanyak 10 orang dengan jumlah persentase sebesar 33,3\%. Hal ini menunjukan bahwa kapasitas petani dalam membangun jejaring kerja/bermitra sudah termasuk baik karena petani mampu melakukan interaksi antar sesama dan membuka diri terhadap bentuk-bentuk kerjasama. Faktor yang terakhir yaitu kapasitas petani dalam mengevaluasi usahatani menunjukan bahwa kategori tinggi berjumlah 3 orang dengan jumlah persentase sebesar 10,0\%, kategori sedang sebanyak 14 orang dengan jumlah persentase sebanyak $47,7 \%$ dan kategori rendah 13 orang dengan jumlah persentase sebesar 43,3\%. Hal ini menunjukan bahwa sebagian besar kapasitas petani dalam melakukan kegiatan evaluasi ini sudah cukup baik akan tetapi perlu adanya perbaikan 
kelompok tani supaya kegiatan kelompok tani seperti pelatihan, diskusi perencanaan sampai dengan evaluasi dapat dilakukan dengan baik sehingga tujuan pelaksanaan usahatani dapat terwujud.

\section{Faktor-Faktor Yang Mempengaruhi Kapasitas Petani}

Analisis faktor - faktor yang mempengaruhi kapasitas petani pada usahatani jagung menggunakan analisis regresi linier berganda dengan menggunakan alat bantu software SPSS versi 25. Faktor yang dikaji terdiri dari tiga diantaranya karakteristik petani, faktor pendukung dan penyelenggaraan usahatani. Berdasarkan hasil analisis, faktorfaktor yang mempengaruhi kapasitas petani dalam usahatani dapat dilihat pada tabel berikut.

Tabel 1 . Analisis Regresi Linier Berganda Karakteristik Petani, Faktor Pendukung dan Penyelenggaraan Penyuluhan Terhadap Kapasitas Petani

\begin{tabular}{|c|c|c|c|c|}
\hline $\mathrm{No}_{0}$ & Traian & $\begin{array}{l}\text { Tnstandardized } \\
\text { Coefficients }\end{array}$ & Sig. & Keterangan \\
\hline & & $B$ & & \\
\hline 1 & $\mathrm{R}^{2}$ & 0,490 & & \\
\hline 2 & Keastanta & 0,814 & 0,058 & \\
\hline 3 & Karakteristik Petani $\left(\mathrm{X}_{1}\right)$ & $-0,021$ & 0,847 & $\begin{array}{c}\text { Tivak } \\
\text { Berpengaruh }\end{array}$ \\
\hline 4 & Faktor Penduhuog $\left(\mathrm{X}_{2}\right)$ & 0,398 & 0,006 & Berpengaruh \\
\hline 5 & $\begin{array}{l}\text { Perrelenggaraan Penyuluhan } \\
\left(\mathrm{X}_{3}\right)\end{array}$ & 0,223 & 0,016 & Berpengaruh \\
\hline
\end{tabular}

Sumber : Data primer diolah penulis, 2020

Berdasarkan tabel diatas $\mathrm{R}^{2}$ (R Square) diperoleh sebesar 0,490 atau sebesar $49,0 \%$ yang dapat dikatakan bahwa faktor karakteristik petani, faktor faktor pendukung dan penyelenggaraan penyuluhan secara bersama-sama mempengaruhi mempengaruhi kapasitas petani dalam mengidentifikasi potensi. Sedangkan $51,0 \%$ dipengaruhi oleh faktor luar diluar pengkajian. Pada kolom signifikan anova diperoleh nilai 0,000 yang nilainya $<0,05$ sehingga dapat dikatakan bahwa faktor karakteristik petani, faktor pendukung dan penyelenggaraan penyuluhan secara bersama-sama atau simultan memiliki pengaruh terhadap kapasitas petani dalam mengidentifikasi potensi. Faktor-faktor tersebut dapat dianalisis secara parsial atau sendiri-sendiri dengan melihat pada kolom signifikan t. Berdasarkan hasil analisis secara parsial dengan melihat kolom signifikan $t$ menyatakan bahwa karakteristik petani, faktor pendukung dan penyelenggaraan penyuluhan terhadap kapasitas petani adalah $\boldsymbol{Y}=(1,462)+$ $(0,284) \boldsymbol{X}_{\boldsymbol{1}}+(1,391) \boldsymbol{X}_{2}+(0,151) \boldsymbol{X}_{3}$, pada taraf signifikan 0,05 yang artinya bahwa karakteristik petani memberikan pengaruh senilai -0,021 faktor pendukung memberikan pengaruh sebesar 0,398 dan penyelenggaraan penyuluhan memberikan pengaruh senilai 0,223 . Tabel diatas menunjukan bahwa yang berpengaruh terhadap kapasitas petani adalah faktor pendukung dengan sig $0,006<=\alpha=0,05$ dan penyelenggaraan penyuluhan dengan sig $0,016<\alpha=0,05$.

\section{Strategi Peningkatan Kapasitas Petani Pada Usahatani Jagung}

Strategi yang dilakukan untuk meningkatkan kapasitas petani dalam usahatani jagung adalah dengan melakukan penyuluhan kepada para petani berdasarkan tahapan kapasitas petani dalam pelaksanaan usahatani. Pemilihan materi penyuluhan dilakukan dengan analisis deskriptif dari nilai indikator terendah pada tingkat kapasitas petani.

Berdasarkan hasil analisis menunjukan bahwa indikator mengatasi masalah mempunyai nilai skor terendah dan peringkat satu sehingga perlu ditindaklanjuti menjadi materi penyuluhan karena tingkat petani dalam mengatasi permasalahan/memberikan solusi permasalahan dalam kegiatan usahatani memiliki skor terendah. Permasalahan yang ada setelah dianalisis menunjukan bahwa faktor pendukung menjadi salah satu faktor utama yang berpengaruh terhadap kapasitas petani. Hal ini diperkuat dengan hasil wawancara terhadap para petani bahwa dalam kegiatan usahatani terdapat sarana dan prasarana yang harus tersedia akan ketersediaan sarana dan prasarana masih kurang karena keterbatasan modal. Maka dari itu perlu adanya pembinaan kelompok tani melalui kegiatan penyelenggaraan penyuluhan supaya kegiatan usahatani dapat berjalan dengan baik. 


\section{PENUTUP}

\section{Kesimpulan}

1. Kapasitas petani dalam usahatani jagung di Desa Margaharja daan Desa Margajaya secara umum rata-rata termasuk kedalam kategori sedang yaitu dalam mengidentifikasi potensi, merencanakan usahatani, pelaksanaan usahatani, membangun jejaring dan mengevaluasi usahatani. Mengatasi masalah dalam kegiatan usahatani masih tergolong rendah.

2. Faktor-faktor yang mempengaruhi kapasitas petanni pada usahatani jagung ini yaitu faktor pendukung meliputi kelompok tani, ketersediaan teknologi infrmasi, ketersediaan sarana prasarana dan inovasi serta penyelenggaraan penyuluhan meliputi persiapan penyuluhan, pelaksanaan penyuluhan dan evaluasi.

3. Strategi yang digunakan untuk meningkatkan kapasitas petani dalam melakukan kegiatan usahatani jagung ini yaitu dengan melakukan penyuluhan kepada para petani maupun kelompok tani mengenai cara-cara menyelesaikan permasalahan khususnya dalam penyediaan sarana prasarana supaya kegiatan usahatani dapat berjalan dengan baik

\section{Saran}

Diharapkan untuk pelaksanaan kegiatan usahatani jagung perlu ditingkatkan dengan melakukan perencanaan, penyediaan sarana prasarana dengan baik sebelum melaksanakan usahatani serta diskusi secara berkala untuk mengatasi permasalahan dalam usahatani.

\section{DAFTAR PUSTAKA}

[1]Undang - Undang No 12 Tahun 1992 Tentang Sistem Budidaya Tanaman http://hukum.unsrat.ac.id/uu/uu_12_1992. pdf (Diakses tanggal 23 Februari 2020) [online]

[2]Milen. 2004. Pegangan Dasar Pengembangan Kapasitas. Diterjemahkan secara bebas. Yogyakarta: Pondok Pustaka Jogja.

[3]Programa BPP Kecamatan Sukadana
[4]Undang - Undang Nomor 16 tahun 2006 Tentang Sistem Penyuluhan Pertanian, Perikanan dan Kehutanan

[5]Padmanagara. 2012. Bapak Penyuluhan Pertanian Pengabdi Petani Sepanjang Hayat, Cet.1. Jakarta: PT Duta Karya Swasta.https://sinta.unud.ac.id/uploads/do kumen_dir/4ee3127a09b4aa60f46701bffa 93ad70.pdf (Diakses tanggal 23 Februari 2020) [online]

[6]Undang - Undang Nomor 16 tahun 2006

[7]Slamet, Margono. 2000. Memantapkan Posisi dan Meningkatkan Peran Penyuluhan Pembangunan dalam Pembangunan. Dalam Proseding Seminar IPB Bogor: Pemberdayaan Sumber Daya Manusia Menuju Terwujudnya Masyarakat Madan. Pustaka Wira Usaha Muda.http://repository.usu.ac.id/bitstream/ handle/123456789/63830/Chapter\%20II.p df?sequence $=4 \&$ isAllowed $=y$ (Diakses tanggal 23 Februari 2020) [online]

[8]Karwan, A. Salikin. 2003. Sistem Pertanian Berkelanjutan. Kanisius, Yoyakarta. http://eprints.undip.ac.id/52837/3/BAB_II. pdf. (Diakses tanggal 24 Februari 2020) [online]

[9]Halim Abdul, Achmad T, dan Muhammad Fakhri H. 2000. "Sistem Pengendalian Manajemen". BPFE. Yogyakarta. https://docplayer.info/66463043-Tinjauanpustaka-karakteristik-petani.html.

(Diakses tanggal 05 Februari 2020) [online]

[10]Peraturan Menteri Kementerian Pertanian Nomor.03/Permentan/SM.200/1/2018.

Pedoman Penyelenggaraan Penyuluhan Pertanian

[11]Tulus Tambunan, 2003. Perkembangan Sektor Pertanian di Indonesia, Beberapa Isu Penting. Ghalia Indonesia Jakarta. http://eprints.undip.ac.id. (Diakses tanggal 24 Februari 2020) [online]

[12] Halim Abdul, Achmad T, dan Muhammad Fakhri H. 2000. "Sistem Pengendalian Manajemen". BPFE. Yogyakarta. https://docplayer.info/66463043-Tinjauanpustaka-karakteristik-petani.html. 
(Diakses tanggal 05 Februari 2020) [online]

[13]BPTP BALITBANG KEPRI, 2018.

http://kepri.litbang.pertanian.go.id.

Diakses tanggal 09 Juni 2020) [online]

[14]Herawati, Aida Vitayala Hubeis, Siti Amanah dan Anna Fatchiya. 2016. Kapasitas Petani Padi Sawah (Oryza sativa L.)Irigasi Teknis Dalam Menerapkan Prinsip Pertanian Ramah Lingkungan Di Sulawesi Tengah. 